RICYDE. Revista Internacional de Ciencias del Deporte doi:10.5232/ricyde

Rev. int. cienc. deporte

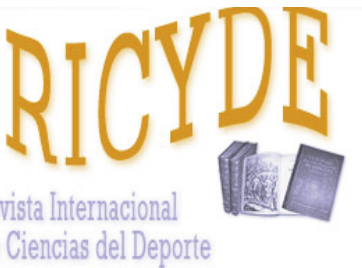

RICYDE. Revista Internacional de Ciencias del Deporte VOLUME XIV - YEAR XIV

Pages:174-187 ISSN:1885-3137

Issue: 52 - April - 2018

\title{
Quality, height, age and home advantage in boxing Calidad, altura, edad y la ventaja de boxear en casa
}

Miguel Pic

Universidad de la Laguna. Spain

\begin{abstract}
The main objective of the present study was the identification of performance indicators in boxing and their impact on the concept of home advantage (HA), among other variables. Professional boxing bouts of the European ranking were selected $(\mathrm{N}=522)$, to generate 1044 units of analysis. ANOVA and T-student analyzes were applied to determine the influence of the difference between boxers in: a) quality, calculated by the number of combats won, opponent's quality, inactivity time, among other indicators; b) height and c) age, depending on the result obtained and the location of the combat. It was also used as an influential variable in the final result. By multivariate analysis (CHAID model), the quality difference between boxers was the most determinant variable $(p<.000)$ to reach the final result, but it was also predictive regarding the combat location $(p<.006)$. The study allowed for revealing determinant effects for the performance in boxing through the crossing of variables and analysis techniques. Suggesting coaches and boxing practitioners to do a thorough review of their training tasks based on the location of their commitments and the boxers' characteristics means they would profit the specificity of each match. The calculation of the risk percentage assumed by professional boxers to achieve success in professional boxing, is one of the practical applications of this research.
\end{abstract}

Key words: boxing; performance; home advantage; result.

\section{Resumen}

El objetivo principal del presente estudio fue la identificación de indicadores de rendimiento en boxeo y su incidencia sobre el concepto de ventaja de jugar en casa (HA), entre otras variables. Fueron seleccionados combates profesionales del ranking Europeo $(\mathrm{N}=522)$ dando lugar a 1044 unidades de análisis. Fueron aplicados análisis ANOVA y T-student para determinar la influencia de la diferencia entre boxeadores en: a) calidad, calculada mediante el número de combates ganados, calidad del oponente, tiempo de inactividad, entre otros indicadores; b) altura y c) edad, en función del resultado obtenido y la localización del combate. También empleada esta como variable influyente en el resultado final. Mediante análisis multivariantes (modelo CHAID) la diferencia de calidad entre los boxeadores era la variable más determinante $(p<.000)$ para alcanzar el resultado final, pero también se mostró predictiva en relación a la localización del combate $(p<.006)$. El estudio permitió desvelar efectos determinantes para el rendimiento en boxeo mediante el cruce de variables y técnicas de análisis. Sugerir a entrenadores y practicantes de boxeo a una revisión profunda de sus tareas de entrenamiento en función de la localización de sus compromisos y las características de los boxeadores, es avanzar en la especificidad de cada combate. Calcular porcentajes de riesgo asumibles por boxeadores profesionales para conseguir éxito en boxeo profesional está entre las aplicaciones prácticas del presente estudio.

Palabras clave: boxeo; rendimiento; ventaja de jugar en casa; resultado.

Correspondence/correspondencia: Miguel Pic

Universidad de la Laguna. Spain

Email: pic.aguilar.90@ull.edu.es 


\section{Introduction}

$\mathrm{B}$ oxing is an opposing (Parlebas, 2001) sport, and it consists of throwing blows against the adversary, who is at a short distance (Amador, 1997). Boxing is also an Olympic sport; the use of head protections, as an Olympic sport, or the prolongation of combat to no more than three rounds, are differences with respect to professional boxing, with bouts of up to twelve rounds, and without protections. Since the Olympic Games in Rio 2016, Olympic boxing became more professional, as the International Olympic Committee (IOC) provided the opportunity for professional boxers to participate in the Olympics. In professional boxing there is not only an organization, since the World Boxing Association (WBA), the World Boxing Council (WBC), the International Boxing Federation (IBF) and the World Boxing Organization (WBO) are internationally recognized. This hinders the uniformity of regulatory aspects.

Studying sports performance (Hughes \& Barlett, 2002; Álvarez, Ortega, Gómez, \& Salado 2009; Gómez, Lago \& Pollard, 2013) demands the identification of precise variables with an impact on the final result. Psychological attributes distinguished successful kickboxers (Slimani, Chaabène, Miarka, Franchini, Chamari \& Cheour, 2017), the strength of punches in different boxing categories (Pierce, Reinbold, Lyngard, Goldman \& Pastore, 2006), a leftoriented fighters' advantage was proved in contact sports (Loffing \& Hagemann, 2015). Age, amount of won and lost combats, and the outcome of the preceding fight was predictive of a fight's outcome (Warnick \& Warnick, 2007). It was pointed out that the last fight and the prior performance against the same boxer, were some of the valid predictors to find out the outcomes in boxing (Warnick \& Warnick, 2009). Also, there is scientific evidence that proves the location or home advantage (HA) effect (Gómez, DelaSerna, Lupo, \& Sampaio, 2014, 2016; Lupo \& Tessitore, 2016; Lago-Peñas, Gómez \& Pollard, 2017).

The HA has been proved in cricket (Morley \& Thomas, 2005), basketball (García, Saéz, Ibañez, Parejo \& Cañadas, 2009), baseball (Levernier \& Barrilla, 2007), volleyball (Marcelino, Mesquita, Palao \& Sampaio, 2009; Marcelino, Mesquita \& Sampaio, 2011), handball (Pollard \& Gómez, 2012), water polo (Gómez, de la Serna, Lupo, \& Sampaio, 2016), rugby (Gómez, Pollard \& Luis-Pascual, 2011) and women's football (Pollard \& Gómez, 2014). In relation to football, the HA has been studied and proved (Lago-Peñas \& Lago-Ballesteros, 2011; Gómez, Gómez-López, Lago \& Sampaio, 2012) in double elimination rounds (Page \& Page, 2007), depending on the round (Pic \& Castellano, 2016; Pic $\&$ Castellano, 2017). The validation of the method for the calculation of HA has been contrasted through different sports disciplines (Pollard \& Gómez, 2012). A study on Muay Thai (Myers, 2014) analyzed the influence of the noise made by the audience on the outcome of the fighting, suggesting the need to address internal and external validity in similar studies.

Other opposing sports such as martial arts have not been left out of the investigation when checking HA (Krumer, 2017). However, the effects of HA in tennis were questioned (Koning, 2011). Continuing with the previous study, the concept of HA was evidenced in qualifying tournaments, but it was especially among highly qualified players when HA showed higher values without distinguishing by gender, the effects disappearing when the quality of both tennis players was low, both in boys and girls.

In judo (Julio, Panissa, Miarka, Takito \& Franchini, 2013), while the boys contrasted the HA by winning more bouts and medals, the girls did not win more bouts but did win more medals than visiting fighters. Later (Julio, Miarka, Rosa, Lima, Takito \& Franchini, 2015) a study was made on the influence of the color of the clothes, finding out effects in both genders and in different competitions. However, in junior and senior categories there were differences that disappeared in pre-juveniles and juveniles. In this sense, in the specialized literature there are 
no relevant data regarding the influence of boxers' age to explain sports performance, although the effect of relative age in fighters (Fukuda, Kelly, Albuquerque, Stout \& Hoffman, 2017) was studied in boxing (Edginton, Gibson \& Connelly, 2014).

However, through the concept of relative age, age is addressed at sparse time scales, which does not allow to confirm whether age can influence the performance of boxers. The prescribing of adequate training in boxing (Slimani, Chaabène, Davis, Franchini, Cheour \& Chamari, 2017; Cunniffe, Ellison, Loosemore \& Cardinale, 2017), the identification of a prior to KO punches formula in heavyweight (Pic-Aguilar, Sánchez-López \& BlancoVillaseñor, 2016) as a situational emergency facing task changes (Hristovski, Davids, Araújo \& Button, 2006; Gómez, Lago \& Pollard, 2013), represent breakthroughs in performance and boxing, but they do not rule out whether height influence in boxing could be considered decisive for a high performance, or whether performance indicators may vary by changing boxers' weight categories (Pierce et al., 2006) or heights.

It is conceivable, then, that boxers need to find strategic solutions to the problems posed by the adversary. In this sense, height in boxing can determine the distance to the opponent, and this fact can reorient the boxers' plan. Specific situations and strategies can be developed by boxers with specific physical dimensions or age. Therefore, the influence of performance indicators in boxing is unknown, as incomplete is the circle of intervening factors (Pollard, 2008) which may affect the already contrasted HA effect.

The existence of HA was confirmed in the Olympic games, depending on the participation of the referee. While in sports subject to referee interpretation there were HA effects, in events such as weight lifting HA was reduced (Balmer, Nevill \& Williams, 2001; Balmer, Nevill \& Williams, 2003). In this sense, in boxing the referee and boxing judges become important to decant the winner. In a boxing match, the boxer proclaimed as the champion is the one who remains standing while the adversary remains on the ground after the referee counts 10 seconds, after accumulating more than two counts of protection, when the referee appreciates that one of the boxers presents inferiority and when a disqualification is decreed.

Also, by decision of the boxing judges, to the conclusion of the agreed assaults a boxer can be the winner. The probability of winning boxing matches thanks to scored points was higher when boxers where local, to the detriment of visitors (Balmer, Nevill \& Lane, 2005), which supported the existence of HA. Specifically, taking control of the quality of boxers it was found that the odds of winning the match fluctuated between 0.57 for knockouts, 0.66 for technical knockouts and 0.74 for points decisions. The differences between the odds referred above with HA values in relation to soccer are not antagonistic, as values $61.12 \%$ in the premier league or the Spanish league 61.66\% (Pollard \& Gómez, 2014a) or 60.20\% (Gómez et al., 2011) prove.

The quality of the boxers showed little consistency in two periods distinguished between 1910-1969, whereas there was statistical support between 1970-2002, which would enable to revitalize the importance of this variable at present (Balmer, Nevill \& Lane, 2005). Continuing with contact sports, in local competitions HA was established in wrestling (Gayton \& Langevin, 1992) with slight effects of $61 \%$ of confrontations in favor of the local fighter and of $54 \%$ related to the visitor, establishing the comparative with the same confrontations under the location condition, in line with other findings (McAndrew, 1993). Evidence was found that pushed to confirm HA for both genders (Krumer, 2017) having control over the quality of the adversary. Also, the organization of events was offered as a way to increase the quality of the national judo teams in the last reference. 
In spite of the support shown by the HA, some reservations (Koning, 2011) have being expressed to explain this phenomenon, even suggesting an inverse HA in hockey (Wright \& Voger, 1995), golf (Wright \& Jackson, 1991) or signs in the semi-finals of the Copa del Rey (Pic \& Castellano, 2017) or in the Uefa Champions League in the same phase of elimination eliminatory phase (Pic \& Castellano, 2016). On the other hand, there is consensus in recognizing that the HA phenomenon is multifactorial (Legaz, Moliner \& Munguía, 2013; Pollard, 2008; Pollard \& Pollard, 2005) but perhaps the key factors haven't been detected, or even the interaction of factors is too complex to understand the HA phenomenon. The inclusion and study of other performance indicators could offer alternative interpretations of performance in boxing and, in turn, modify and / or complete the interpretive circle of HA.

For all the above reasons, it is intended to know what the results obtained in boxing match respond to. Intensifying the discussion from data means advancing to clear the relational complexity of variables in performance and HA in boxing. In addition, the objectives were: 1) to determine the influence of variables susceptible to explain the successful outcome in boxing, 2) to clarify the effect of HA on performance in boxing.

\section{Methodology}

\section{Participants}

The sample of the present study consisted of 522 professional boxing bouts selected from European rankings, half of which belonged to heavyweight, while the remaining half belonged to welter weight. Combats from 2013 to 2016 were included, recognized by international boxing organizations such as World Boxing Association (WBA), the World Boxing Council (WBC), the International Boxing Federation (IBF) and the World Boxing Organization (WBO). The inclusion criteria of this study was: a) the celebration of in heavyweight or welterweight combats, b) only right-handed boxers were included from the sample, due to alleged left-oriented fighters' advantage in combat sports (Loffing \& Hagemann, 2015; Gursoy, 2009; Baker \& Schorer, 2013), c) all boxers and bouts included were registered in Boxrec.com, d) combats finishing by ko (knockout), tko (technical knockout) or points were included.

\section{Variables}

The independent variables (IV) of the study were: weight categories, quality, age and height of boxers. All independent variables were continuous except for weight categories, which assumed the established heavyweight and welterweight categories. The dependent variables (DV) (DV1 or result: win or lose) and (DV2 or location: local, visitor and neutral). The dependent variable (DV2) in the study will act as independent (predictor) one in multivariate analysis.

\section{Procedure}

Data were taken from the official specialized portal (boxrec.com). The classification of the best European boxers of the present time was obtained in the same data portal, corresponding with the heavyweight and welterweight categories. All the combats of each boxer during the years 2013, 2014, 2015 and 2016 were considered, following the criteria of inclusion and exclusion previously referred, beginning with the first classified in the European ranking, reaching 261 heavyweight matches and 261 bouts of welterweight. The extraction began with the first two classified in their respective classifications, specifically with the British boxer Anthonny Josua in heavyweight and Amhir Kahan in welterweight. 
The quality of the boxers was extracted from the same database (boxrec). The quality (Balmer et al., 2005) of boxers ranged from 721 positive and negative points. That is, an amplitude of 1442 points of maximum difference or 0 points when the boxers had an identical aprioristic quality, before starting the combat.

The procedure followed by the portal is explained in the portal itself. Boxers are ranked according to a ranking model (Stefani \& Pollard, 2007) based on the strength of the opponents to calculate the value of each victory or defeat. Thus, defeating a high scoring opponent generates a lot of profit, whereas defeating a lower opponent implies modest improvement in the ranking. On this model of classification, originally used in chess based in Arpard Emrick Elo model, improvements of adjustment such as the penalization of the inactivity times of the boxers, among others, were included.

Each boxing match was made up by two different statistical units, corresponding to each of the boxers in each match. Thus, once the construction of the database was completed, the registered values of each combat between boxer A and boxer B were subtracted from the continuous variables (quality, age and height) and vice versa. Thus, a height difference of 10 centimeters favorable to boxer A over boxer B would be represented by 10 centimeters favorable to boxer A, but would mean 10 centimeters negative with respect to boxer $\mathrm{B}$. In order to do this, a similar procedure, recently applied to football, was followed (Lago-Peñas, Gómez \& Pollard, 2017).

A boxer was considered to have won a match by ko (knockout), tko (technical knockout) or by points, while he would lose it by the same ways. The location variable was made operative by considering the place of residence and birth (Balmer et al., 2005). That is, a) if the match coincided with the birth or residence place of boxer A exclusively, then boxer A was local, while boxer B was a visitor; B) if neither of the two boxers had been born or resided in the place where the combat was going to take place, it was considered as a neutral location; and finally c) was equally neutral, if both boxers were resident or had been born at the place of celebration of the combat.

\section{Data Analysis}

First, a multivariate analysis (CHAID) Growing Method (SPSS v.24) (Morgan \& Sonquist, 1963) was performed, with cross validation and minimum cases in parent node (100) and minimum cases in child node (50). From the independent variables (IV: weight categories, location, height, age, quality) on the first dependent variable (DV1: result). Then, the same analysis was made, but starting this time from location (figure 2) on the second dependent variable (DV2: location), and including the result variable, as independent, (IV: weight categories, result, height, age, quality).

Given the compliance with the normality and homogeneity assumptions of variances, for the variables age and height as a function of location (DV2) and result of the combat (DV1), the ANOVA test of one factor was first performed, taking age and height (IV) to test the null hypothesis or no significant differences in the location variable (DV2). Following with parametric tests, a T-student was practiced taking (IV: age and height) and (DV1: wins or loses), that is to say, result of the combat.

Due to the low homogeneity of the quality variable, a nonparametric analysis path was proposed. In the case of the location variable (DV2), the Kruskal-Wallis test was used, while the same process was followed with the result variable (DV1) through the Mann-Whittney test. A significance level $(\mathrm{p}<.05)$ was assumed for all the analyses. 


\section{Results}

By using the hierarchical segmentation technique of classification trees (figure 1) it was shown that the outcome (DV1) obtained by the boxers depended mainly on their quality ( $p$ $<.001$, Chi square $=161,930)$ (between nodes $1-4)$ and secondly, on their age $(\mathrm{p}<.000)$ (between nodes 5-10). For the location (figure 2) of the combats (DV2) a first independent variable was shown as the result of the combat $(\mathrm{p}<.000$, Chi square $=252,583)$, and in the second level the location was segmented by the weight categories $(p<.000)$ of the fighters (nodes between 3-6). Finally, in the last level (between nodes 7-10), the quality $(p<.006)$ of the boxers was found.

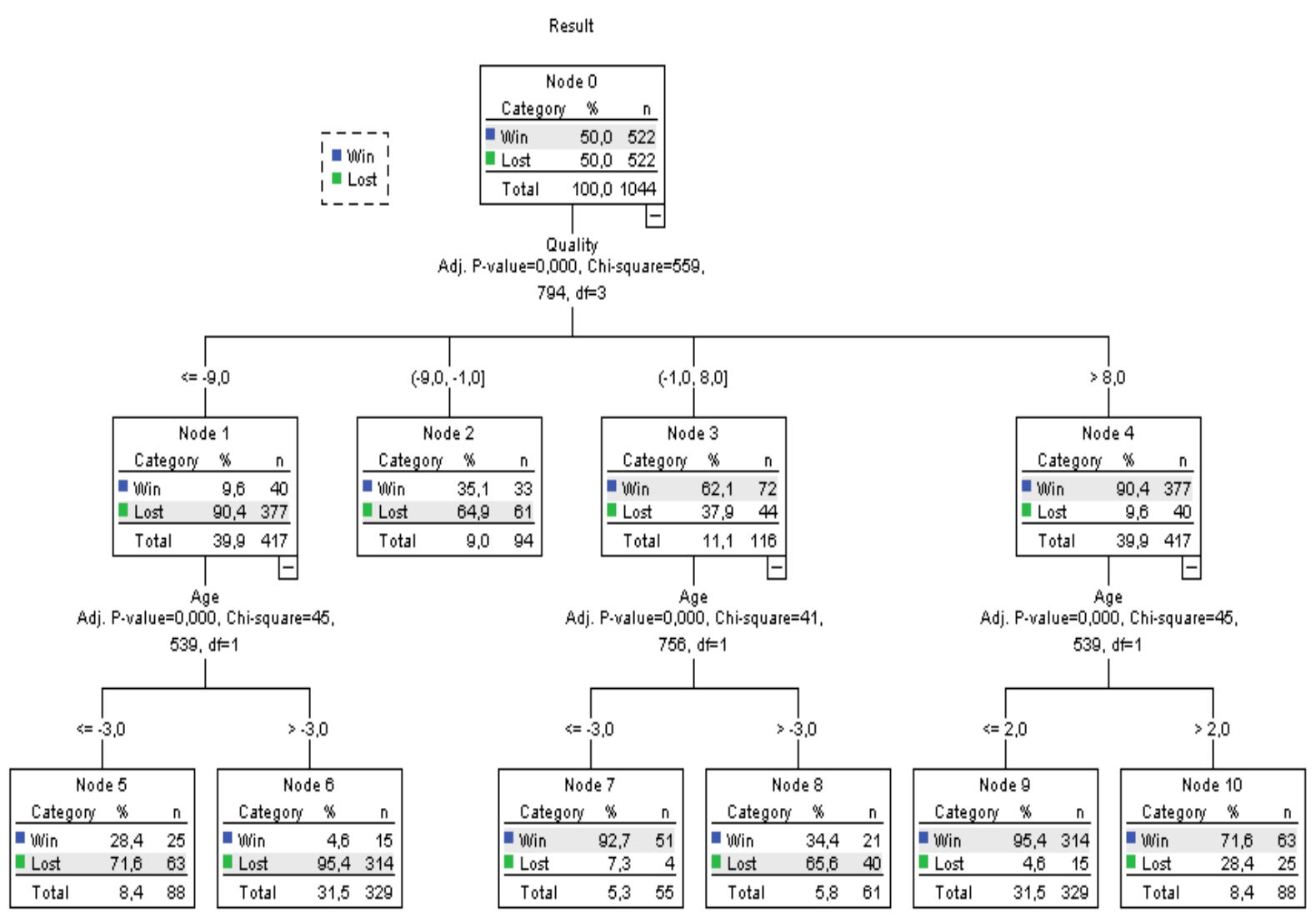

Figure 1: Tree of predictive variables taking into account weight categories (heavy/welter), location, height, age and quality over combat result.

In Figure 1, 86.8\% of the cases were correctly classified. It was verified that the result variable was branched by 4 nodes in quality groups $(p<.000)$. With values of quality equal to or less than negative values at 9 , losing was frequent $(\mathrm{n}=337,90.4 \%)$ while victory was scarce $(n=40,9.6 \%)$. Then, by means of age at node $5(\mathrm{p}<.000)$, it was verified that being three years younger than the rival or less did not imply success, since few victories were obtained by defeats in node 5. Regarding the previous values, they made losses grow increasing the age difference in more than three years from three years younger than the rival on $(\mathrm{n}=314,95.4 \%)$ in node 6 . Based on the differences in quality of node 3 , it was found that starting from a three year younger or less difference between boxers $(p<.000)$ produced a majority of victories and few defeats. But by increasing the age difference to more than three years from negative values of 3 of node 8 , the losses increased $(n=40,65.6 \%)$ and the wins decreased, with respect to node 7 . 
Starting from node 4, where the differences between winners and losers with percentages around $85 \%$ intensified, age had influence on this branch of node 9 with an age difference of two years or less on the opponent, with a proportion of victories greater than $90 \%$ on the defeats. However, when the age difference increases to more than two years of advantage over the rival, the percentages of the previous node were balanced. Specifically, node 10 recorded a number of wins $(n=63,71.6 \%)$ and losses $(n=25,28.4 \%)$.

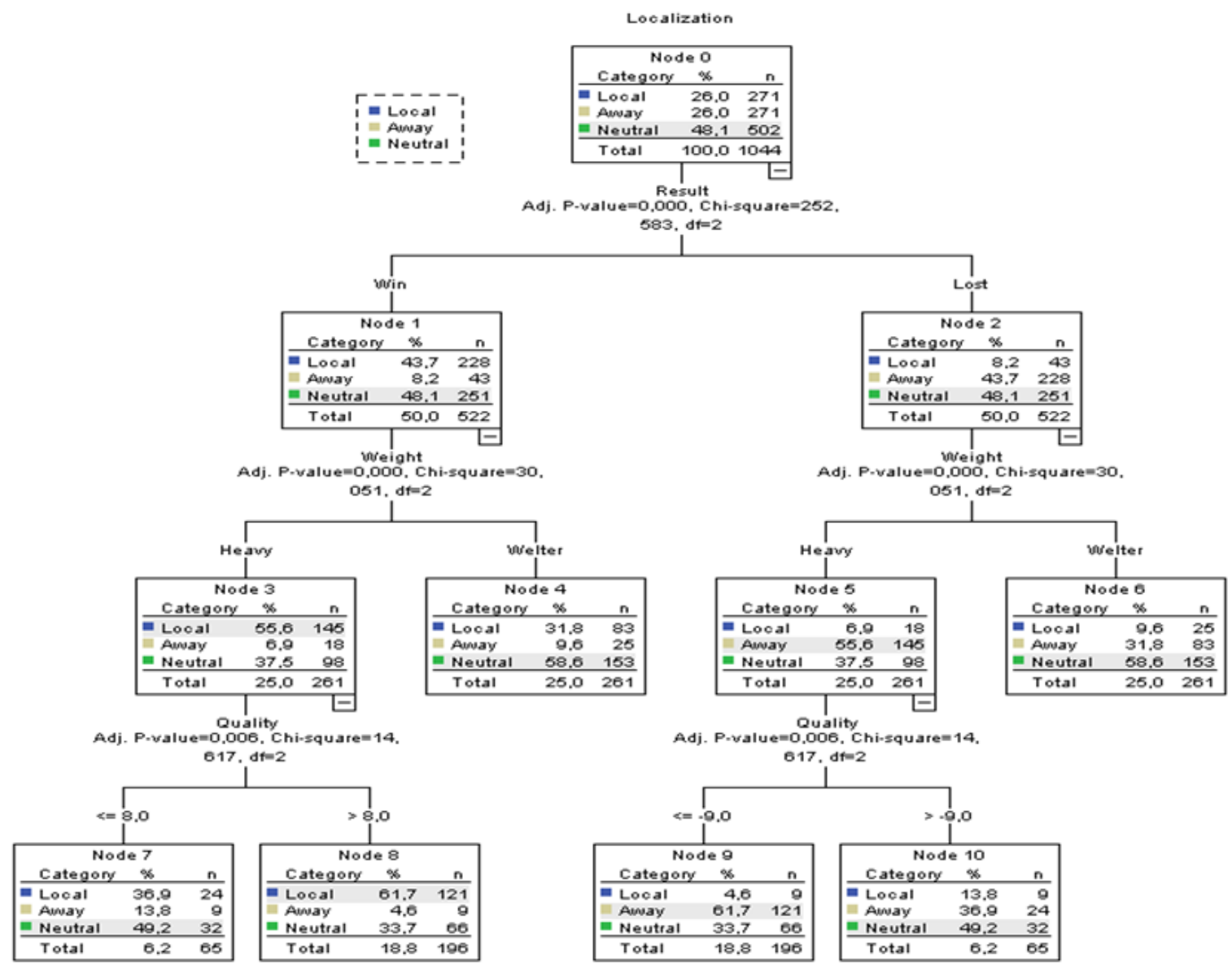

Figure 2: Tree of predictive variables taking into account weight category (heavy/welter), height, age, result and quality over boxing location.

In Figure 2, 58.6\% of the cases were adequately classified according to the CHAID classification model. Of 271 local or visiting statistics, roughly half of the matches were neutral, but this value does not change from node 1 to node 2 because, if the location was neutral, it means that a neutral boxer will win and another one will lose. However, when examining the local and visiting values of node 1 , it was verified that there were differences in the number of local winning boxers $(n=228,84 \%)$ with a smaller amount $(n=43,16 \%)$ on the visiting side. These values were reversed by examining the units of lost combats (node $2)$, since local obtained $(n=43,16 \%)$ while winning $(n=228,84 \%)$. The 3-6 nodes obtained statistical support $(\mathrm{p}<.000)$ from weight categories variable. Both won and lost matches were distinguished by weight categories.

In the heavyweight group, they won local matches $(n=145,55.6 \%)$ and lost $(n=18,6.9 \%)$, while local welterweight won $(n=83,31.8 \%)$ and lost $(n=25,9.6 \%)$. Nodes 5-6 mirror 3-4 since a winning bout by a boxer means that another boxer lost. The records obtained in the previous nodes through the category of heavyweight were branched. Differences in quality 
among boxers $(p<.006)$ on winning were set by values less than or equal to 8 (node 7 ). With this previous difference in quality, local boxers obtained the victories $(n=24,36.9 \%)$ on the visiting and neutral ones. However, after increasing the value of quality difference to more than 8 points (node 8$)$, local boxers obtained $(n=121,61.7 \%)$, visitors $(n=9,13.8 \%)$ and neutral $(\mathrm{n}=66,33.7 \%)$. In nodes 9 and 10 a mirror relation of the previous nodes takes place. However, the quality was established from the value less than or equal to 9 negative (node 9) and higher (node 10).

In order to be able to accept the alternative hypothesis that there was a difference of means (DV1: win or lose), according to height difference and age difference, the significance level should be less than 0.05 . By means of the T-student test, it must reach values of more than 2 or below 2. It was accepted the alternative hypothesis that there were heterogeneous variances in the difference of heights based on winning or losing. The differences in height $(\mathrm{p}<.05)$ and age $(\mathrm{p}<.05)$ were thus determinant for success in the fight. The winning boxers surpassed their rivals in height $(3.12 \mathrm{~cm})$, while losers were shorter $(-3.12 \mathrm{~cm})$. Boxers younger than their rivals ( -4.34 years) obtained victories and the increase in the age of the boxers (4.34 years) represented lost combats. By means of the (non-parametric) rank test, it was possible to conclude that quality was conclusive $(\mathrm{p}<.000)$, reflecting a higher quality average in winning boxers (732.99) than in those who lost (312.01).

It was accepted, by ANOVA analysis, the alternative hypothesis of existence of differences in the mean of the categories of the location (DV2) variable due to the influence of height and age difference. Both obtained high levels of significance $(p<.000)$ less than $(p<.05)$. They were distributed with an optimal value f higher than the minimum required value (3.84), and it was observed that the height difference had a value of $\mathrm{f}=21,642$ followed by the variable age difference with a value of 43,752 . While mean height values showed that local boxers were taller $(2.23 \mathrm{~cm})$ than visitors $(-2.23 \mathrm{~cm})$, local boxers were younger $(-3.21$ years $)$ than visitors (3.21 years). It was obtained by Kruskal-Wallis non-parametric test, with a chi-square value of $220,312(\mathrm{p}<.000)$ that supported the determination of boxers' quality for the location of the combat with average values of local boxers (714.73), visitors (330.27) and neutral ones (522.50).

\section{Discussion}

This research fulfilled the objectives contemplated by the analysis of variables and itineraries through which the specific performance in boxing circulated. The same variables and itineraries were used to explain the concept of HA, also used as an explanatory variable of performance in boxing since its conception as a multifactorial phenomenon (Legaz et al., 2013; Pollard \& Pollard, 2005; Boyko, Boyko \& Boyko, 2007). High competitive sports performance (Hughes \& Barlett, 2002; Álvarez et al., 2009) needs a situational study (Gómez et al., 2013) to better know the success cues in boxing, discriminating the incidence of HA on the final result.

The boxers with higher quality, older and taller were mostly successful (victories). The incidence of height over boxers' victory was contrasted. However, caution is recommended, since this variable $(\mathrm{p}<.05)$ did not appear in Figure 1. On the other hand, the influence of variables age $(\mathrm{p}<.000)$ (Warnick \& Warnick, 2007), height $(\mathrm{p}<.000)$ and quality $(\mathrm{p}<.000)$ on location (DV2) offered keys that helped characterize (Pic-Aguilar et al., 2016) local boxers with higher quality, taller and younger than visitors. Thus, while higher quality and height were identified with victories and local combats, the age variable made both dependent variables differ. That is, while local boxers were younger, victories in boxing required boxers who were older than their opponents. These results define a performance model in boxing in 
tune with the local role of the location variable. In other words, victory and boxing at home described parallel paths, which only differed because of age (Edginton et al., 2014).

Therefore, in this sense, it is considered that the HA concept can be enriched with other variables to better understand the behavior of HA (Pollard, 2008), through performance variables (Álvarez et al., 2009; Gómez et al., 2013). It should be added in this sense that the height and quality identified with local boxers and excellent results (winning) may represent keys that should be studied from a confluence approach, that is, not just studying performance partially, but combined with the concept of HA.

The importance of aprioristic quality in explaining the results was highlighted as the first explanatory variable (figure 1). Starting from a quality from 1 negative to more than 8 , they were $39 \%$ of the records, of these with 409 victories represented $77 \%$ of the total. Other researches have shown consistency in the influence of athletes' quality in handball (Oliveira, Gómez \& Sampaio, 2012), water polo (Gómez et al., 2016), judo (Krumer, 2017), tennis (Koning, 2011), and boxing (Balmer et al., 2005). The adversary's quality effect on tennis was important when studying HA exclusively with high-quality opponents, but not with inferior opponents (Koning, 2011). In his study on handball (Gómez, Lago-Peñas, Viaño \& GonzálezGarcía, 2014) showed the influence of quality, which was a consistent predictor of the type of local or visiting boxing victory (Balmer et al., 2005), depending on the period of analysis.

Regarding boxers' quality, some previous studies confirmed our conclusions (Balmer, et al, 2005). Following these authors, victories at home were more substantial when competing as a local, supporting the existence of HA, especially when combats must be decided by the judges (Balmer et al., 2001; Balmer et al., 2003).

The lack of correlation between boxers who belong to the same weight category in relation to the force of the impacts, showed the non-specificity by weight category (Pierce et al., 2006). As we saw in figure 2, the appearance of the weight category variable between nodes 3-6, warning of the importance of quality in heavyweight to organize the location of the clashes, did not correspond to the welterweight. This fact can be interpreted as symptomatic, between the location of the combats and the quality in heavyweight. Perhaps, in order to explain this fact, we have to resort to the percentages of won local combats $(\mathrm{n}=145,55.6 \%)$, visiting $(\mathrm{n}=$ $18,6.1 \%)$ and neutral ones $(n=98,37.5 \%)$. However, under the same conditions in welterweight local won combats were $(\mathrm{n}=83,31.8)$, visiting $(\mathrm{n}=25,9.6 \%)$ and neutral ones $(\mathrm{n}=153,58.6 \%)$. The greater number of neutral welterweight combats suggested a reduction in quality differentials among boxers. On the other hand, the difference between the number of local and visiting units in heavyweight was higher $(\mathrm{n}=127 ; 49.1 \%)$ than in welterweight $(\mathrm{N}=58,22.2 \%)$.

Considering the local and visiting combats exclusively it was shown that, in heavyweight, having more than 8 favorable points against the rival meant to reach HA values around $93 \%$, while starting from values equal to or less than 8 quality points implied 37\% HA. However, these differences between heavyweight and welterweight might respond to a greater need to influence the outcome on heavyweight over welterweight. It should not be forgotten that heavyweight has been paid more attention, historically at least. Thus, not only was heavyweight identified with winning when boxing at home, but also with a structured quality difference (figure 2), other than welterweight.

Among the most relevant applications of the present study it would be the prediction of the winner and the profits that could be derived from it. The performance itineraries depending on the variables and their linkage with HA reveal hidden messages to a superfluous look. The boxers can be helped by a planning of the most appropriate training, as the quality, age, height, weight category of the opponent and location of the combat should not be ignored, as 
well as their own indicators for the preparation of professional matches. On the other hand, to discriminate in a better way the combats with options of victory on the part of the boxers, at least according to a conscious and assumed risk, would be between the applications of the present writing.

More research would be needed to identify the variables capable of capturing the specific performance in boxing, as well as the influence of and on HA. As suggested limitations for future research, a quality neutralization process was not performed to reveal if quality balanced combats obtained better results when competing as a local or a visitor boxer. It would be risky to be conclusive with the results that were found due to several reasons. Some limitations need to be cited to help future researchers. The scarcity of specialized literature in boxing analysis from a performance and HA approach supposed a limitation. The number of participants should be increased in order to be able to more easily generalize the results achieved. One limitation of the study would be not being able to specify the specific models of success in boxing, since it was decided to make a calculation of the differences between the boxers, combat by combat. The quality variable should be grouped into quality categories to better understand its effects. Finally, it would be important to apply a validated procedure (Pollard \& Gómez, 2012) because, although in boxing the proportion of matches finishing in a draw is scarce, it should be included.

\section{Conclusion}

The difference in quality conditioned the outcome and location of the matches but the age difference of the boxers was different depending on the result or HA. Height, greater in victorious boxers than in defeated ones, was identified with local boxers and not with visiting ones.

Heterogeneity was demonstrated in boxers' weight category (Pierce et al., 2006) depending on the combat location, with the psychological factor in performance being pointed out by authorized voices (Warnick \& Warnick, 2009). The same authors remarked that previous results and age were determinants to winning, which was supported by our study. On the other hand, the concept HA was contrasted, specifying the origin of this advantage. Therefore, investigations with performance variables could be indicated, including the location of the boxing matches, in order to address the variations of the enigmatic HA phenomenon and its influence on the specificity of the result, among other variables, in professional boxing. Unveiling decisive variables in boxing offers the opportunity to optimize efforts in the performance of this sport.

\section{References}

Amador, F. (1997). Clasificación de los juegos y deportes de lucha. En: El Judo y las ciencias de la educación física y el deporte. Vitoria: IVEF-SHEE, 5-22.

Álvarez, A.; Ortega, E., Gómez, M. A., \& Salado, J. (2009). Estudio de los indicadores de rendimiento defensivos en baloncesto de alto rendimiento. Cuadernos de Psicología del Deporte, 9(Suppl), 71.

Baker, J., \& Schorer, J. (2013). The Southpaw Advantage?-Lateral Preference in Mixed Martial Arts. Plos One, 8(11), 1-3 e79793.

https://doi.org/10.1371/journal.pone.0079793

Balmer, N. J.; Nevill, A. M., \& Williams, A. M. (2001). Home advantage in the Winter Olympics (1908-1998). Journal of Sports Sciences, 19(2), 129-139.

https://doi.org/10.1080/026404101300036334 
Balmer, N. J.; Nevill, A. M., \& Williams, A. M. (2003). Modelling home advantage in the Summer Olympic Games. Journal of Sports Sciences, 21(6), 469-478. https://doi.org/10.1080/0264041031000101890

Balmer, N. J.; Nevill, A. M., \& Lane, A. M. (2005). Do judges enhance home advantage in European championship boxing? Journal of Sports Sciences, 23(4), 409-416.

https://doi.org/10.1080/02640410400021583

Boyko, R. H.; Boyko, A. R., \& Boyko, M. G. (2007). Referee bias contributes to home advantage in English Premiership football. Journal of Sports Sciences, 25(11), 11851194.

https://doi.org/10.1080/02640410601038576

Cunniffe, B.; Ellison, M.; Loosemore, M., \& Cardinale, M. (2017). Warm-up Practices in Elite Boxing Athletes: Impact on Power Output. The Journal of Strength \& Conditioning Research, 31(1), 95-105. https://doi.org/10.1519/JSC.0000000000001484

Edginton, R.; Gibson, R., \& Connelly, C. (2014). Exploring the relative age effect and nation dominance in Olympic boxing, a review of the last decade. Procedia Engineering, 72(1), 805-810.

https://doi.org/10.1016/j.proeng.2014.06.136

Fukuda, D. H., Kelly, J. D., Albuquerque, M. R., Stout, J. R., \& Hoffman, J. R. (2017). Relative age effects despite weight categories in elite junior male wrestlers. Sport Sciences for Health, 13(1), 99-106.

https://doi.org/10.1007/s11332-017-0351-z

García, J., Sáez, J., Ibáñez, S. J., Parejo, I., \& Cañadas, M. (2009). Home advantage analysis in ACB league in season 2007-2008. Revista de psicología del deporte, 18(suppl), 331-335.

Gayton, W. F., \& Langevin, G. (1992). Home advantage: Does it exist in individual sports. Perceptual and Motor Skills, 74(3), 706-706.

https://doi.org/10.2466/pms.1992.74.3.706

Gómez, M.A.; Lago-Peñas, C., Viaño, J., \& González-García, I. (2014). Effects of game location, team quality and final outcome on game-related statistics in professional handball close games. Kineziologija, 46(2), 249-257.

Gómez, M. A.; Pollard, R., \& Luis-Pascual, J. C. (2011). Comparison of the home advantage in nine different professional team sports in Spain. Perceptual and motor skills, 113(1), 150-156.

https://doi.org/10.2466/05.PMS.113.4.150-156

Gómez, M. A.; Gómez-López, M.; Lago, C., \& Sampaio, J. (2012). Effects of game location and final outcome on game-related statistics in each zone of the pitch in professional football. European Journal of Sport Science, 12(5), 393-398. https://doi.org/10.1080/17461391.2011.566373

Gómez, M. A.; Lago, C., \& Pollard, R. (2013). Situational variables. Routledge Handbook of Performance Analysis in Sport. London and New York: Routledge.

Gómez M.A.; DelaSerna A.; Lupo C., \& Sampaio J. (2014). Effects of Situational Variables and Starting Quarter Score in the outcome of elite women's water polo game quarters. International Journal of Performance Analysis in Sport, 14(1), 73-83.

Gómez, M. A.; DelaSerna, A., Lupo, C., \& Sampaio, J. E. (2016). Effects of game location, quality of opposition, and starting quarter score in the outcome of elite water polo quarters. The Journal of Strength \& Conditioning Research, 30(4), 1014-1020. https://doi.org/10.1519/JSC.0b013e3182aa5f59

Gursoy, R. (2009). Effects of left-or right-hand preference on the success of boxers in Turkey. British Journal of Sports Medicine, 43(2), 142-144.

https://doi.org/10.1136/bjsm.2007.043547 
Hristovski, R.; Davids, K.; Araújo, D., \& Button, C. (2006). How boxers decide to punch a target: emergent behaviour in nonlinear dynamical movement systems. Journal of sports science \& medicine, 5(CSSI), 60-73.

Hughes, M. D., \& Barlett, R. (2002). The use of performance indicators in performance analysis. Journal of Sports Sciences, 20(10), 739-754.

https://doi.org/10.1080/026404102320675602

Julio, U. F.; Panissa, V. L. G.; Miarka, B.; Takito, M. Y., \& Franchini, E. (2013). Home advantage in judo: A study of the world ranking list. Journal of Sports Sciences, 31(2), 212-218.

https://doi.org/10.1080/02640414.2012.725855

Julio, U. F.; Miarka, B.; Rosa, J. P.; Lima, G. H.; Takito, M. Y., \& Franchini, E. (2015). Blue Judogi may bias competitive performance when seeding system is not used: Sex, age, and level of competition effects. Perceptual and motor skills, 120(1), 28-37. https://doi.org/10.2466/30.PMS.120v15x2

Koning, R. H. (2011). Home advantage in professional tennis. Journal of Sports Sciences, 29(1), 19-27.

https://doi.org/10.1080/02640414.2010.516762

Krumer, A. (2017). On winning probabilities, weight categories, and home advantage in professional judo. Journal of Sports Economics, 18(1), 77-96.

https://doi.org/10.1177/1527002514560576

Lago-Peñas, C., \& Lago-Ballesteros, J. (2011). Game location and team quality effects on performance profiles in professional soccer. Journal of Sports Science and Medicine, $10(3), 465-471$.

Lago-Peñas, C.; Gómez, M. A., \& Pollard, R. (2017). Home advantage in elite soccer matches. A transient effect?. International Journal of Performance Analysis in Sport, $17(1-2), 86-95$.

https://doi.org/10.1080/24748668.2017.1304024

Legaz-Arrese, A.; Moliner-Urdiales, D., \& Munguía-Izquierdo, D. (2013). Home advantage and sports performance: evidence, causes and psychological implications. Universitas Psychologica, 12(3), 933-943.

https://doi.org/10.11144/Javeriana.UPSY12-3.hasp

Levernier, W., \& Barilla, A. (2007). The home-field advantage in Major League Baseball. The Berkeley Electronic Press, 3(1), 1-22.

Loffing, F., \& Hagemann, N. (2015). Pushing through evolution? Incidence and fight records of left-oriented fighters in professional boxing history. Laterality: Asymmetries of Body, Brain and Cognition, 20(3), 270-286.

https://doi.org/10.1080/1357650X.2014.961471

Lupo C., \& Tessitore A. (2016). How important is the final outcome to interpret match analysis data: the influence of scoring a goal, and difference between close and balance games in elite soccer. Comment on Lago-Peñas and Gómez-Lopez. Perceptual \& Motor Skills, 122(1), 280-285.

https://doi.org/10.1177/0031512515626629

Marcelino, R.; Mesquita, I., Palao, J., \& Sampaio, J. (2009). Home advantage in highlevel volleyball varies according to set number. Journal of Sports Science and Medicine, 8(3), 352-356.

Marcelino, R.; Mesquita, I., \& Sampaio, J. (2011). Effects of quality of opposition and match status on technical and tactical performances in elite volleyball. Journal of Sports Sciences, 29(7), 733-741.

https://doi.org/10.1080/02640414.2011.552516 
Miarka, B.; Vecchio, F. B. D.; Brito, C. J.; Tabben, M.; Amtmann, J., \& Chamari, K. (2016). Effects of home advantage in Mixed Martial Arts performance with paired bouts of the same fighting opponents. International Journal of Performance Analysis in Sport, 16(3), 948-960.

McAndrew, F. T. (1993). The home advantage in individual sports. The Journal of social psychology, 133(3), 401-403.

https://doi.org/10.1080/00224545.1993.9712160

Myers, T. D. (2014). Achieving external validity in home advantage research: generalizing crowd noise effects. Frontiers in psychology, 5(1), 1-7.

https://doi.org/10.3389/fpsyg.2014.00532

Morgan, J. N., \& Sonquist, J. A. (1963). Problems in the analysis of survey data, and a proposal. Journal of the American statistical association, 58(302), 415-434.

https://doi.org/10.1080/01621459.1963.10500855

Morley, B., \& Thomas, D. (2005). An investigation of home advantage and other factors affecting outcomes in English one-day cricket matches. Journal of sports sciences, 23(3), 261-268.

https://doi.org/10.1080/02640410410001730133

Oliveira, T.; Gómez, M., \& Sampaio, J. (2012). Effects of game location, period, and quality of opposition in elite handball performances. Perceptual and motor skills, 114(3), 783-794.

https://doi.org/10.2466/30.06.PMS.114.3.783-794

Page, L., \& Page, K. (2007). The second leg home advantage: Evidence from European football cup competitions. Journal of Sports Sciences, 25(14), 1547-1556.

https://doi.org/10.1080/02640410701275219

Parlebas, P. (2001). Juegos. deportes y sociedad. Léxico de praxiología motriz. Paidotribo: Barcelona.

Pic-Aguilar, M.; Sánchez-López, C. R., \& Blanco-Villaseñor, A. (2016). Caracterización del "Knock out" en Boxeo. Cuadernos de Psicología del Deporte, 16(1), 85-94.

Pic, M., \& Castellano, J. (2016). Efecto de la localización del partido en eliminatorias de ida y vuelta de la UEFA Champions League. RICYDE. Revista Internacional de Ciencias del Deporte, 44(12), 149-163.

https://doi.org/10.5232/ricyde2016.04405

Pic, M., \& Castellano, J. (2017). Influence of match location in the spanish Copa del Rey. Retos, 31(1), 202-206.

Pierce, J. D.; Reinbold, K. A.; Lyngard, B. C.; Goldman, R. J., \& Pastore, C. M. (2006). Direct measurement of punch force during six professional boxing matches. Journal of Quantitative Analysis in Sports, 2(2), 1-17.

https://doi.org/10.2202/1559-0410.1004

Pollard, R. (2008). Home advantage in football: A current review of an unsolved puzzle. The Open Sports Sciences Journal, 1(1), 12-14.

https://doi.org/10.2174/1875399X00801010012

Pollard, R., \& Gómez, M. A. (2012). Re-assessment of home advantage in Spanish handball: comment on Gutierrez, et al. (2012). Perceptual and motor skills, 115(3), 937943.

https://doi.org/10.2466/06.05.PMS.115.6.937-943

Pollard, R., \& Gómez, M. A. (2014). Comparison of home advantage in men's and women's football leagues in Europe. European journal of sport science, 14(suppl), 77-83. https://doi.org/10.1080/17461391.2011.651490 
Pollard, R., \& Gómez, M. A. (2014a). Components of home advantage in 157 national soccer leagues worldwide. International Journal of Sport and Exercise Psychology, 12(3), 218-233.

https://doi.org/10.1080/1612197X.2014.888245

Slimani, M.; Chaabène, H.; Miarka, B.; Franchini, E.; Chamari, K., \& Cheour, F. (2017). Kickboxing review: anthropometric, psychophysiological and activity profiles and injury epidemiology. Biology of Sport, 34(2), 185-196.

https://doi.org/10.5114/biolsport.2017.65338

Slimani, M.; Chaabène, H.; Davis, P.; Franchini, E.; Cheour, F., \& Chamari, K. (2017). Performance Aspects and Physiological Responses in Male Amateur Boxing Competitions: A Brief Review. The Journal of Strength \& Conditioning Research, 31(4), 1132-1141. https://doi.org/10.1519/JSC.0000000000001643

Stefani, R., \& Pollard, R. (2007). Football rating systems for top-level competition: a critical survey. Journal of Quantitative Analysis in Sports, 3(3), 1-20.

https://doi.org/10.2202/1559-0410.1071

Warnick, J. E., \& Warnick, K. (2007). Specification of variables predictive of victories in the sport of boxing. Perceptual and motor skills, 105(1), 153-158.

https://doi.org/10.2466/pms.105.1.153-158

Warnick, J. E., \& Warnick, K. (2009). Specification of variables predictive of victories in the sport of boxing: II. Further characterization of previous success. Perceptual and motor skills, 108(1), 137-138.

https://doi.org/10.2466/pms.108.1.137-138

Wright, E. F., \& Jackson, W. (1991). The home-course disadvantage in golf championships: Further evidence for the undermining effect of supportive audiences on performance under pressure. Journal of Sport Behavior, 14(1), 51-60.

Wright, E. F., \& Voyer, D. (1995). Supporting audiences and performance under pressure: The home-ice disadvantage in hockey championships. Journal of Sport Behavior, 18(1), 21-28. 